\title{
Migrants' Narratives on Urban Governance: A Case from Kolkata, a City of the Global South
}

\author{
Anuradha Chakrabarti ${ }^{1,2, *(D)}$, Reena Tiwari ${ }^{2}$ and Haimanti Banerji ${ }^{1}$ \\ 1 Department of Architecture and Regional Planning, Indian Institute of Technology Kharagpur, \\ Kharagpur, WB 721302, India; haimanti@arp.iitkgp.ernet.in \\ 2 School of Design and Build Environment, Curtin University, Perth, WA 6945, Australia; \\ R.Tiwari@curtin.edu.au \\ * Correspondence: anuradha.chakrabarti@postgrad.curtin.edu.au
}

check for updates

Citation: Chakrabarti, A.; Tiwari, R.; Banerji, H. Migrants' Narratives on Urban Governance: A Case from Kolkata, a City of the Global South. Sustainability 2021, 13, 1009. https:// doi.org/10.3390/su13021009

Received: 22 December 2020

Accepted: 11 January 2021

Published: 19 January 2021

Publisher's Note: MDPI stays neutral with regard to jurisdictional claims in published maps and institutional affiliations.

Copyright: (c) 2021 by the authors. Licensee MDPI, Basel, Switzerland. This article is an open access article distributed under the terms and conditions of the Creative Commons Attribution (CC BY) license (https:// creativecommons.org/licenses/by/ $4.0 /)$.

\begin{abstract}
The paper aims to reveal the politics of urban governance and the associated impact on the lives of disenfranchised migrants. It critically explores the urban governance structure and the nature of practices involved in the cycle of settlement, eviction, resistance and resettlement. The case of Nonadanga, located at the urban margin of Kolkata, India, was explored for this purpose. An ethnographic methodology comprising observation, semi-structured interviews and oral history was adopted for the research. Twelve squatter dwellers and four experts working in Nonadanga and Kolkata were interviewed for this purpose. A three-step data analysis comprising a narrative approach, thematic network analysis and validation was adopted. A critical review of inclusive practices, together with ethnographic survey findings, demonstrates that migrants live in a condition the paper calls "partial rights", which is a manifestation of the dialectics of inclusiveness practiced by the urban governance structure and derived from the interaction between urban governance structure and migrants' agency. By analyzing past development trends, the paper outlines possible future scenarios for migrants' living conditions and discusses their impact on achieving the targeted Sustainable Development Goal 11 for inclusive cities by 2030.
\end{abstract}

Keywords: urban governance; squatters; inclusiveness; SDG; Kolkata; India

\section{Introduction}

Global challenges such as climate change, migration, security and a more fragile and fluctuating global economy have created greater demands on the services required from sub-national and local government, the key executors of ground-level policies and strategies. At the same time, urban governance constraints around fiscal and autonomy in decision making [1-4] have resulted in massive exploitation and corruption at the local level. The reason behind this trend is that urban governance operates "not in a vacuum" but as a political process tackling negotiation, lobbying pressure, democratic concerns at various levels of government and governance. Especially in the countries of the Global South, the future shape of cities is impacted by local urban governance that extends beyond the policies, rules and regulations to everyday interactions and negotiations, resistance and compliance between the governed and the actors in the urban governance structure [5-10].

In these cities, the role of urban governance has shifted from a facilitator to a beneficiary $[1,11-13]$, which is counteracted by the agency of the marginalized $[6,10]$, who play an equally important role in shaping urban governance practices through their informal ways of interacting, resisting and complying with the governance system. The governance system also allows such interaction because of its inability to serve everyone equally and to continue getting the electoral support of the urban poor to stay in power. Within this context, this paper aims to answer, first, how the urban governance practices of Kolkata affect inclusiveness and the quality of life of poor urban migrants in Nondanga and, second, 
can Kolkata become an inclusive city as per the Sustainable Development Goal (SDG) 11.1 by 2030 , considering the present governance trends and attitudes toward migrants?

Historically, Kolkata, the capital city of the state of West Bengal, has witnessed a constant influx of migrants, who can be temporally classified into three primary streams. During the British era, inter-state migrants came to work in jute mills and other industries along the bank of the Hugli river. Over time, this stream dwindled, but even today, migrants from the neighbouring states of Bihar, Orissa and Jharkhand continue to come to Kolkata in smaller numbers [14,15]. When India received its independence from British rule in 1947, until the end of the 1970s, Kolkata witnessed a regular influx of political refugees from Bangladesh. These refugees were political migrants from erstwhile East Pakistan and present-day Bangladesh, after its independence from East Pakistan in 1971 [16]. Kolkata, being the largest city located in proximity to the India-Bangladesh border, was a magnet for the migrants. More recently, border control measures have reduced this influx, but illegal trespassing from Bangladesh into Kolkata still continues. Even though the overall migration to Kolkata declined in 2000, neo-liberal politics have created a demand for labour, which is catered for by inter-state and intra-state migrants [17]. Since 2000, a stream of climate change migrants from nearby areas of Sundarban have been added to the migrant pool of Kolkata.

Kolkata's urban margins, where most of the newly arriving poor migrants live, have been rapidly transforming and are at the center of urban politics discourse [18]. A complicated narrative unfolds between urban governance actors who adopt a neo-liberal world city aspiration for Kolkata and the governed, i.e., the urban poor migrants. These actors are operating in the politics of the future development of urban land and its use rights. Literature shows that where such interactions are steered by urban governance, the result can be a large-scale violation of democratic rights, evictions, anti-eviction movements and negotiations [19].

Nonadanga, located in the eastern corner of Kolkata, is characterized as a part of the urban margin but officially included in Ward No. 108 of Kolkata Municipal Corporation (KMC). Nonadanga is a transforming space where a conflict between local governance actors and poor urban migrants centers around urban land occupancy. Theoretically, Nonadanga can be categorized as "grey space", as proposed by Yiftachel [7]. These are spaces between the "'lightness' of legality/approval/safety and the 'darkness' of eviction/destruction/death. Grey spaces are neither integrated nor eliminated, forming pseudo-permanent margins of today's urban regions, partially existing outside the gaze of state authorities and city plans" [7]. The paper explores how in Nonadanga, illegal land transactions under the purview of local governance actors activated large-scale squatter developments in the second half of 2010. What followed was a cycle of eviction (2013), resistance, negotiation and resettlement that continues to haunt the everyday lives of poor urban migrants in Nonadanga.

The people of Nonadanga endure similar living conditions to people living in the urban margins of historic cities such as Delhi, Mumbai and Bengaluru in India and in many cities of the Global South, where historic core and periphery dwellers are caught between development and deprivation from neo-liberal capital, labor and governance practices [7,19-21]. Nonadanga is not an isolated case but one that is replicated across the globe.

While most previous studies focus on measuring urban governance's efficacy from data available from government agencies and surveys [1], this paper diverges from this approach to view urban governance as an evolving process shaped by local circumstances, demands, and politics that can be read through the interaction between governance structure and the agency of the people at the grassroots. Owing to a lack of data and covert interactions between local urban governance actors and the governed, not captured in papers or data $[6,22]$, the paper shows that an ethnographic approach to exploring the interaction between governance agencies and poor urban migrants is more suitable for exploring questions on inclusiveness and sustainability in the Global South context. 
The paper is structured in six parts. Following the introduction, Section 2 establishes the theoretical background of the paper, which is structure-agency interaction. Next, Section 3 outlines the ethnographic methodology adopted for the research, following which, Section 4 provides an account of the historical background and urban governance in Kolkata. Section 5 presents the results under the theme-dialectics of inclusivenessthat emerge from structure-agency interaction in Nonadanga. This section is further subdivided into five sub-sections. Together they produce a critical perspective of migrants' lived experience, which the paper calls "partial rights". Next, Section 6 presents the discussion; by drawing on partial rights, this section presents three scenarios with varying SDG 2030 outcomes for Kolkata.

\section{Theoretical Background}

A review of the urban governance literature points to a theoretical shift from urban "government to governance" and from "managerialism to entrepreneurialism" that provides a relevant theoretical underpinning for running cities for a considerable period [23,24]. This shift is further widening the gap between the "democratic side" and the "administrative side" of urban governance by dividing issues of democracy, rights and inclusion from legality, power, control and vote bank politics [24]. Cruz [1] identifies the need for research to engage with issues on both sides. In doing that, he notes, researchers should move from a piecemeal approach to researching keywords such as "unequal power, democratization, representation and public perception", regarding their effects in totality on the pursuit of wider societal goals, which remain less researched. The urban governance literature also shows a "lack of critical approach" [25] that has ignored "community voices" [1]. Thus, a demand for new research to accommodate community voices that narrate the entrepreneurial role of urban governance practices in shaping their quality of life remains to be explored to its full potential.

The United Nation's Sustainable Development Goals (SDGs) suggest that the primary objective of urban governance is to promote inclusivity and sustainability [26]. SDG 11.2 proposes making cities inclusive by 2030. A critical reading of the SDG framework shows that it ignores the complex ground realities under which the urban governance systems operate in the Global South $[27,28]$. Furthermore, by adopting a top-down approach, the framework shows the government as the sole provider and ignores the agency of the people at the grassroots in shaping urban management practices [29]. This statedriven/reformist approach has been criticized by scholars from the Global South and East, who call it a Euro-centric or a Western approach $[29,30]$. David Harvey critiques this "reformist understanding" of the state as a "legitimate beginning" by noting that it reduces rights to a "political turf" by making it insufficient "as a horizon of strategic goals and a general framework for thinking and action" [2,30]. By accepting the reformist approach as North and West-centric, Global South scholars have instead emphasized understanding the everyday life and agency of the people at the grassroots [26,31]. Partha Chatterjee [6] calls this process the "politics of the governed". Yieftachel [7] shows how urban transformation occurs through an interaction "from above", through governance, and "from the below", through grassroots agency, in the urban margins. Recent research identifies the need to expand and explore inclusiveness in the Global South through an intersection of urban governance (from above) and human agency (from below) [7,29]. Henri Lefebvre shows that rights in the urban context are not given but are achieved through "participation", "appropriation" and the creation of "value" in the urban life of its marginalized subjects [32].

In a similar line, Anthony Giddens, in his Structuration theory, used the structureagency interaction as a relevant underpinning to explore societal changes [33]. Giddens's theory situates practices as a manifestation of the interaction between human agency and structure, where human actions are in continuity with the past. He conceptualized structures not as a barrier to actions but as an essential dimension to the production and modification of newer practices. Similarly, the influence of neo-liberal market forces 
on urban governance practices has already changed their role from managerial to entrepreneurial, to facilitate the need for exclusion and extraction, the basic principles on which neo-liberalism operates [11-13]. To analyze the entrepreneurial role of urban governance in Kolkata, the study used the structure-agency interaction. This perspective of urban governance in urban research, not as a subject but as an object, in which various actors at different levels of the governance structure foster, regulate and steer towards newer methods of interaction with the governed and vice versa, is critical to the study of larger societal outcomes such as inclusiveness and sustainability. The study applied the theory of structure-agency interaction to understand the interaction between urban governance and the agency of the poor by examining their living conditions in Nonadanga and future sustainability.

However, being based on practices, structure-agency interaction tends to exhibit an overemphasis on cognition by presenting a relatively disembodied view of the agent [34], here, the migrant. This theoretical limitation is acknowledged by the paper, by including a section on the political and social consciousness of the migrant attributed to their embodied perception (Section 5.4). This sub-section on migrants' consciousness counterbalances the limitation of structure-agency interaction as primarily disembodied.

\section{Ethnographic Methodology and Materials}

Ethnographic data were collected through observation and semi-structured interviews, oral histories supported by visual methods. Using multiple methods ensured a triangulation approach to the research. As shown in Table 1, a three-stage process of a pilot survey, data collection and validation led to data collection and analysis from August 2018 to December 2019.

Table 1. Research stages.

\begin{tabular}{ccc}
\hline Stage & Objective & Activities \\
Stage I & Pilot fieldwork & $\begin{array}{c}\text { Site identification, identification of gatekeepers, } \\
\text { pilot fieldwork and analysis }\end{array}$ \\
\hline Stage II & Fieldwork & $\begin{array}{c}\text { Identifying respondents, conducting in-depth } \\
\text { interviews, observation and photography }\end{array}$ \\
\hline Stage III & Validation & Discussing findings with experts, visiting sites \\
and validation
\end{tabular}

The research began by identifying the above-mentioned organizations working for the urban migrants in Kolkata. Expert interviews were conducted, and key sites in Nonadanga were identified. With the help of experts, contact with migrants of Nonadanga was established. Initial field visits were made with members of Majdur Kranti Parishad. Key members/gatekeepers in the settlement were identified, and a snowball method was adopted to identify other respondents. Initially, multiple visits over a period of two months were made to Nonadanga. These visits helped to establish relationships with the dwellers, following which interviews were conducted. First, a pilot survey was conducted, and its data were analyzed. This led to the identification of the structure-agency interaction as a suitable approach. In the next stage, fully fledged interviews were conducted with the respondents. Post-analysis, the results and construction of future scenarios were shared with the experts and respondents for validation.

Morse's qualitative research methodology requires at least five subjects to validate the nature of experience [35]. Hence, ten semi-structured interviews were conducted with four expert interviews. Three female and seven male residents of Nonadanga squatter settlements were interviewed. The details of which are shown in Table 2 
Table 2. Age distribution of male and female respondents in Nonadanga.

\begin{tabular}{|c|c|c|}
\hline \multirow[t]{2}{*}{ Squatter settlement } & Male (4) & $\begin{array}{l}\text { Age: }(25-30)-1 ;(31-41)-1 \text {; } \\
\quad(41-60)-1 \text {; above } 60-1\end{array}$ \\
\hline & Female (1) & Age: $(41-50)-1$ \\
\hline \multirow{2}{*}{$\begin{array}{l}\text { Resettlement colony (evictees } \\
\text { from squatter settlements who } \\
\text { were resettled) }\end{array}$} & Male (3) & $\begin{array}{c}\text { Age: }(25-30)-1 ;(31-41)-1 ; \\
(41-60)-1\end{array}$ \\
\hline & Female (2) & Age: $(20-30)-1 ;(31-40)-1$ \\
\hline
\end{tabular}

The questionnaire for the semi-structured interviews was divided into broad sections: the migration history of individual migrants, the urban experience in Kolkata, the role of urban governance in Nonadanga, and quality of life pre and post-eviction. The interviews were recorded and, on average, lasted for two hours. Respondents' original names were changed to maintain privacy.

Oral histories were collected from the four experts on Kolkata, migrants and urban governance. Each data set was crosschecked and validated by secondary documents. The life-long work of experts with migrants of Kolkata and especially with Nonadanga supplied the research with its contextual history. These interviews were audio recorded. The experts were from organizations such as Majdur Kranti Parishad, the Association for Protection of Democratic Rights (APDR), and Nagarik Mancha, who, over the years, have been actively involved in Kolkata's politics and have been a constant support to the migrants in Nonadanga.

Analysis of the data was carried out in three stages: (A) After the pilot survey, the first round of data analysis was completed. For this stage, we followed a narrative analysis where underlying themes emerged from migrants' stories [36]. Here, structure-agency interaction was identified as underpinning this research. (B) Next, patterns emerging from the empirical data were identified. For this stage, the research followed AttrideSterling's [37] Thematic Network Analysis, which identified three types of themes: (a) the basic themes presented in Sections 5.1-5.4; (b) the grouping of basic themes to develop organizing themes, which is presented in Section 5.5; (c) the global theme, which refers to the main narrative- the impact of the dialectics of inclusiveness and partial rights on future sustainability, as presented in Section 6.

\section{Historical Background of Nonadanga}

Since 1970, the eastern and south-eastern margins of the city have witnessed largescale land appropriation [16], by an influx of refugees from Bangladesh. An exodus of Hindu refugees from the Muslim-majority Bangladesh was fueled by large-scale communal riots in the country. The West Bengal government's failure to provide resettlement land to these people resulted in the forceful occupancy and conversion of marshy land into habitable neighborhoods [38]. The government subsequently provided physical and social infrastructure to these refugee resettlement colonies, making these areas habitable. Currently, there are mid- to low-income families in this neighborhood.

In early 2000, Nonadanga, located further east of these refugee resettlement colonies, was a marshy inhabitable land on which KMC resettled Kolkata's urban poor from squatter settlements along railway lines, high drains and other precarious locations in the city [39]. In 2005, a city-level Kolkata Environment Improvement Project was launched to make Kolkata slum-free [40]. A condition of the Asian Development Bank, the funding agency (meeting 69\% of the project cost), was in situ resettlement or rehabilitation for dwellers, where eviction was unavoidable. From the five sites chosen as resettlement colonies for this project, 3468 families were selected to be resettled in Nonadanga [41,42]. With the rapid eastward development and expansion of Kolkata, a demand for cheap labor resulted in the development of new informal squatters close to the resettlement colony in Nonadanga.

During the first decade of 2000, Kolkata's eastern and south-eastern parts, where huge chunks of vacant land were available, witnessed massive development. The Eastern 
Metropolitan Bypass construction changed the dynamics of the area, of which Nonadanga is a part, by connecting it to the airport and other parts of the city [34]. These developments made Nonadanga and the adjoining areas lucrative for real-estate investment. According to a Land Use and Urban Development Plan (LUDCP), the Kolkata Metropolitan Development Authority (KMDA) was considering giving a 99-year lease to a private developer for a comprehensive development plan for Nonadanga [43]. An increasing squatter settlement in Nonadanga was an impediment to such a move by the government. In 2013, there was a massive eviction drive by KMC, met with a long-drawn protest by the migrants of Nonadanga, which eventually forced KMC to provide resettlement and stall future evictions.

\section{Results: Dialectics of Inclusiveness in Urban Governance Practices and the Manifestation of Partial Rights}

The dialectics of inclusiveness emerge as a theme from the structure-agency interaction in Nonadanga. Analysis of the data shows that there exist wide-scale contradictions in the practices of urban governance in Nonadanga compared with the universal goal of inclusiveness in Kolkata. The dialectic of inclusiveness exists within a binary logic embedded in the very core of city's existence [44], between cities and people, where the urbanization of consciousness has necessitated an urban revolution, and a struggle for the right to the city is commonly heard from inclusive smart cities. Such contradictions expose the reality of the lived experience of the marginalized population, and show, methodologically, that the dialectics of inclusiveness are an apposite way to understand the contradictions entrenched in city life. These contradictions are likely to direct the city's future development trajectory.

The section concludes by drawing on an argument of partial rights using the dialectics of inclusiveness as a theme emerging from the interaction between structure and agency from the field. Here, the dialectics of inclusiveness are analyzed through four points: development-induced eviction and resettlement due to political pressure, quality of life in the resettlement colony, negotiating fundamental rights, and political and social consciousness. Each point has been shown as a dialectic to inclusiveness in Kolkata.

\subsection{Development-Induced Eviction, Resettlement and Inclusiveness}

The migrants of Kolkata are the subjects of neoliberal politics that has escalated the demand for informal workers in the city and encouraged people to migrate for work to the city. However, unaffordable high-rental and squatter-clearance programs, which are the primary settlement means for migrants, have kept migrant inclusion partial in the city. The victims of such urban-governance-induced neo-liberal practices of eviction and resettlement have led to the massive migration of the urban poor from different parts of the city to Nonadanga. The development of Nonadanga is a manifestation of the government-induced development trajectory adopted for the larger space-Kolkata. Current developments in Kolkata are caught between the state's dialectic inclination towards neo-liberal development, which demands the appropriation of urban land for developing high-end real-estate, and [18] the city's long-lived political attitude of being pro-poor. Any change to public support for the poor would have electoral implications for political parties. Government authorities are generally careful with eviction drives in Kolkata.

The local governance structure referred to in this paper constitutes a multitude of actors at different levels of KMC. These are the Mayor, ward councilors and grass-root political cadres managing urban governance. Figure 1 depicts this urban governance structure and the unfolding of event sin Nonadanga. 


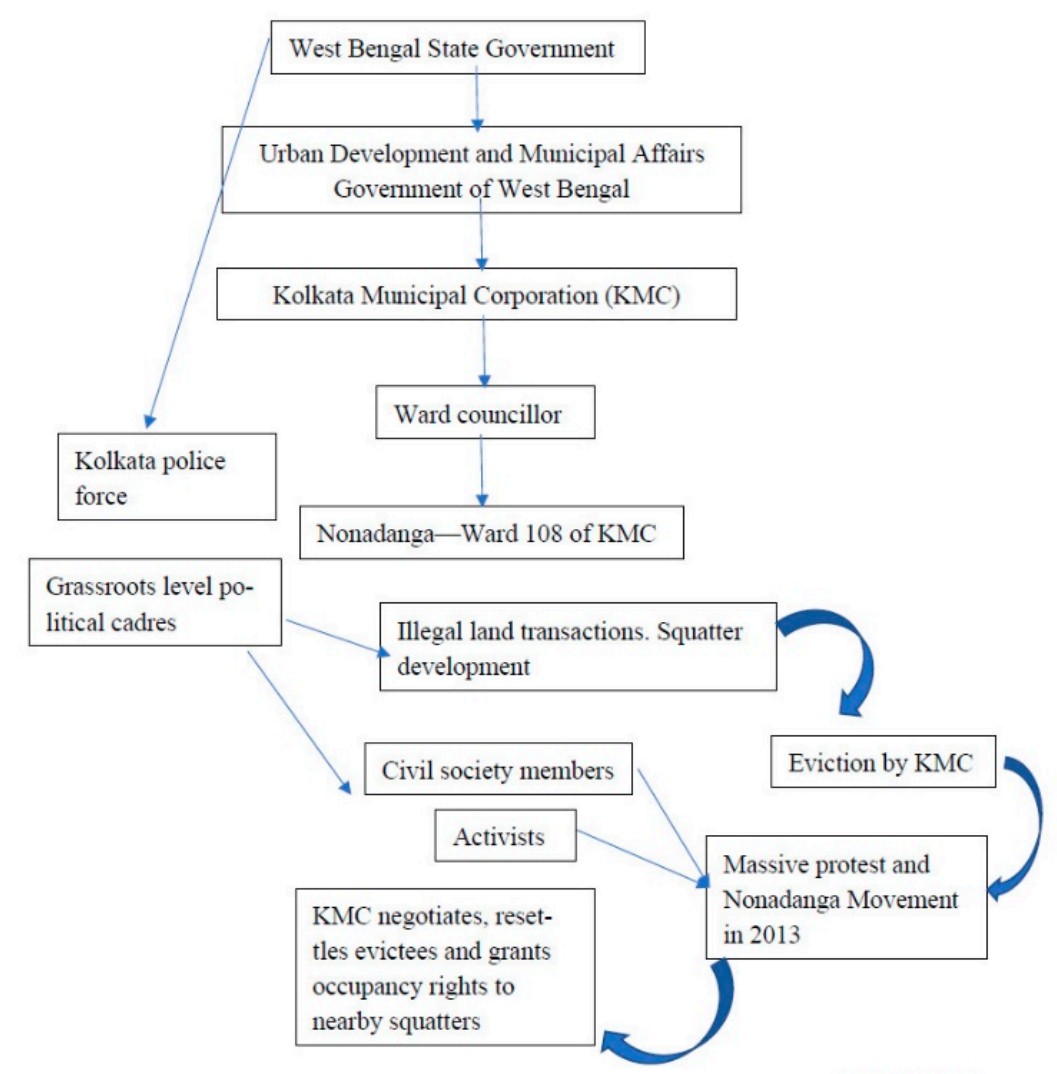

Figure 1. Mapping the role of various actors of the urban governance structure in the transformation of Nonadanga. Source: Author.

The political grassroots networks played a significant role in a land transaction in Nonadanga. Assisted by grassroots political workers, poor migrants were able to buy land in the China Mandir ground in Nonadanga. Land in India is a state subject, making it possible for State Governments, urban governance authorities and police forces in conjunction with local grassroots party workers to manage land allocation and landuse responsibilities. The local political cadres-under police supervision and against "protection money", the colloquial term for a bribe, ranging between INR 5000 and 10,000provided occupancy rights to migrants. This attracted the large-scale migration of poor migrants from different parts of the city to Nonadanga, which soon transformed into make-shift squatter settlements. In 2009, the squatter numbers were further increased with climate change victims (from Aila, the super-cyclone in 2009) pouring into the city and settling in Nonadanga. During interviews, migrants corroborated the involvement of state police and local political party workers in land dealings. Ananya Roy's [22] book on Calcutta (presently Kolkata) shows how land at the urban margin of Kolkata is kept out of records to facilitate illegal transactions under urban governance vigilance.

These transactions under partial state gaze are a neo-liberal manifestation of the urban government's covert interaction with its marginalized populace. More and more informal squatters sprouted in and around the China Mandir ground, making Nonadanga a space for the marginalized.

Meanwhile, adjoining land parcels around Nonadanga were developing rapidly, which had a rippling effect on land prices and demand in Nonadanga. The increasing squatters of Nonadanga became a threat to real-estate development in and around Nonadanga. In early 2013, ignoring any form of resistance, KMC handed eviction notices to the squatter dwellers. Following that, in April 2013, a massive eviction drive by KMC razed a significant number of squatter settlements, rendering hundreds homeless (Figure 2a,b)). The victims immediately launched a massive protest movement that went on for months. 
Help from civil society, activists and media against KMC's atrocity and use of police force to silence the evictees' voices intensified the ongoing protest (Figure 2c,d). After months of protest and under political pressure, KMC announced resettlement for the evicted dwellers and no further evictions for any of the other existing squatters in Nonadanga, bringing the long-drawn protest movement to an end.

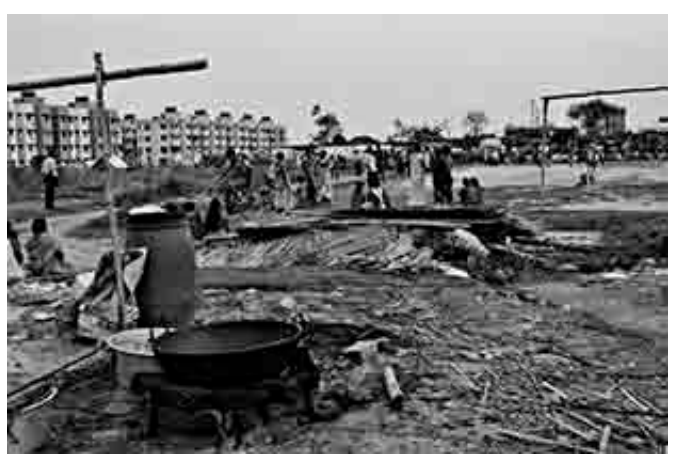

(a) Image 1: Aftermath of eviction

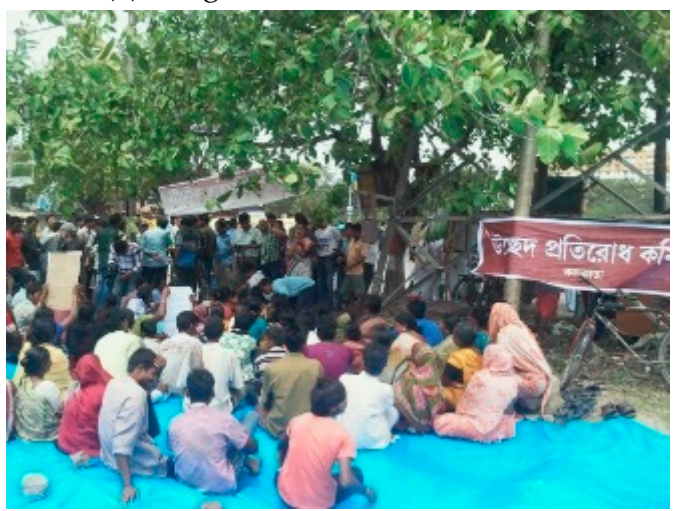

(c) Image 3: Nonadanga movement

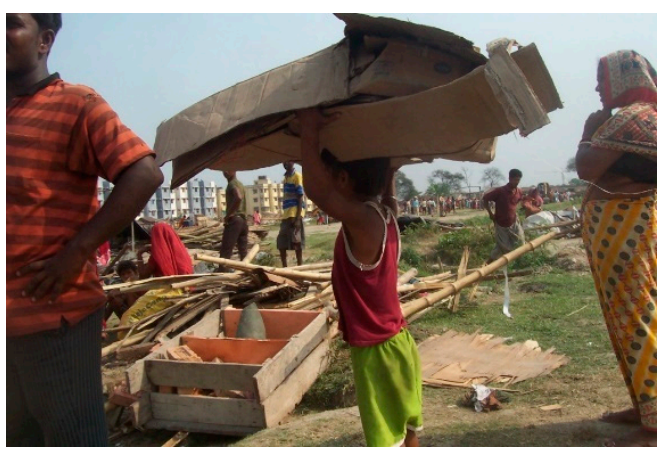

(b) Image 2: Aftermath of eviction

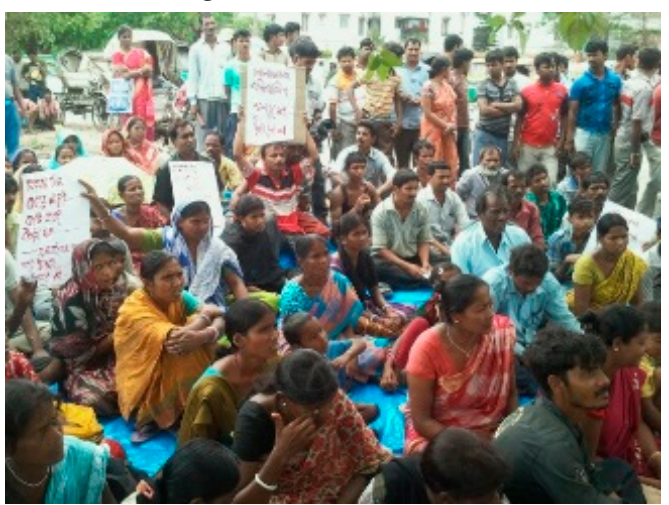

(d) Image 4: Nonadanga movement

Figure 2. The aftermath of the Nonadanga eviction (a,b). An ongoing Nonadanga Movement in 2013 (c,d). Source: (a) Image 1: http:/ / www.archive.cpiml.org/liberation/year_2012/may_2012/feature_2.html, (b) Image 2: https: / / kractivist.org/ appeal-for-action-forcible-eviction-in-nonadanga-kolkata/, (c,d) Images 3 and 4: http://sanhati.com/articles/4775/\#14.

The structure-agency interaction in Nonadanga points to two things: First, the poor are not organically included by the urban governance process in city-making. As a result, they resort to extra-legal means to secure their position in the city. This makes them "permanent temporaries" in the city narrative [17]. The urban governance actors play a significant role in facilitating extra-legal transactions; in the Nonadanga case, there was informal land dealing between grassroots political workers and poor urban migrants under the supervision of police and with the knowledge of the Ward Councillor. Second, the inclusion or exclusion of the "permanent temporaries" depends on their bargaining power with the city administrators. KMC did not resettle all the evictees in Nonadanga. The protesting evictees' bargaining power determined the number of households eligible for resettlement. Post-Nonadanga movement, all squatter dwellers were included in the electoral list, corroborating their political inclusion as citizens of Kolkata and making inclusion a political rather than a human rights subject. Their quality of life in the postresettlement phase, which is discussed in the next section, shows blatant human rights violation in Nonadanga.

\subsection{Quality of Life in the Resettlement Colony and Inclusiveness}

This sub-section assesses the dwellers' quality of life in the resettlement colony as an important parameter of inclusiveness. Excerpts of the interviews and observations show that the resettlement colony was constituted of typical one-room huts made of tile and 
with a plastic-covered roof, located adjacent to a high drain, carrying pitch-dark sludge and a breeding ground for mosquitoes (Figure $3 a-d$ ). Seventy-two resettlement units are concentrated on a small block of land between the main road and the high drain. Due to the lack of space, some households are extending their activities to the road, which is dangerous, and accidents have occurred. The toilets are located at both ends of the stretch of huts (Image e), but a lack of maintenance has left only one of them in proper operating condition. To avoid any inconvenience caused from it, some dwellers have made makeshift toilets outside their huts (Image f). There is no individual water supply line to households. Water has one point source and needs to be carried from there to parts of the colony. Sabita (34), a female resident of the resettlement colony, notes, "We were much happier in the China Mandir ground in Nonadanga. There was more space, and it was comfortable. Here, there is no space to move. We have been cramped up in these huts in the name of resettlement". The smell from the high drain cannot escape visitors' olfactory senses. Even though they have got used to the smell, the residents mention it becomes unbearable after rain. "The government has indeed resettled us, but you see how we are living", says Soma (25). She adds, "My children cannot go out; the road is too busy and risky. Can you see there (pointing to the roof), the hut is slowly tilting towards the high-drain? We do not know how safe it is for us to live here". Moreover, there is a constant risk of malaria and other diseases in the colony. The threat of another eviction is not ignored by the dwellers, who mention a plan of converting the land on which the resettlement colony stands into a parking lot by the Honda showroom located across the road. They came to know about this plan from an advertisement by Honda showing a parking lot in the place of the colony, which was removed after resistance from the dwellers. The quality of the infrastructure in the resettlement housing and threats of eviction expose the inclusiveness rhetoric practiced by KMC.

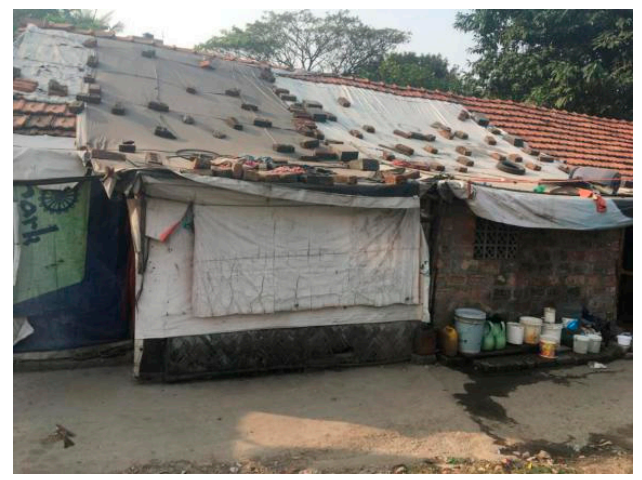

(a) Image 1: Resettlement huts

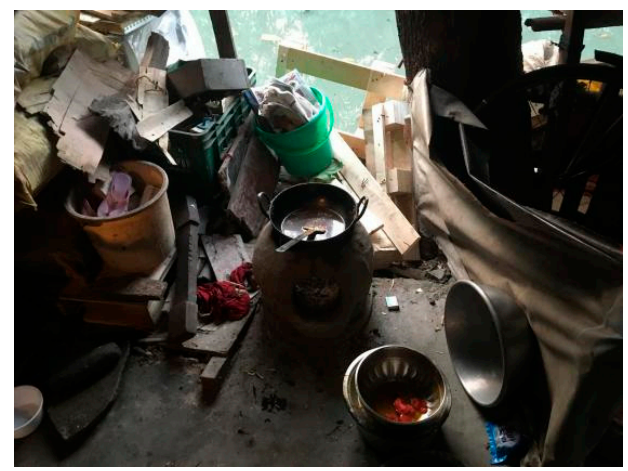

(c) Image 3: A makeshift extension of the hut to produce a cooking area

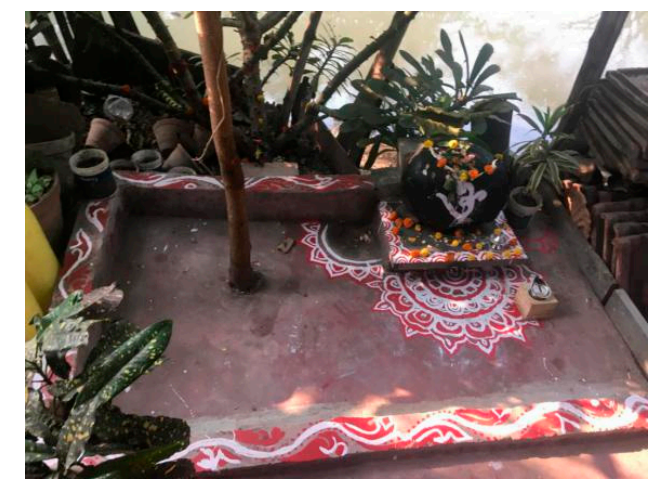

(b) Image 2: A prayer house in the colony adjacent to the high drain

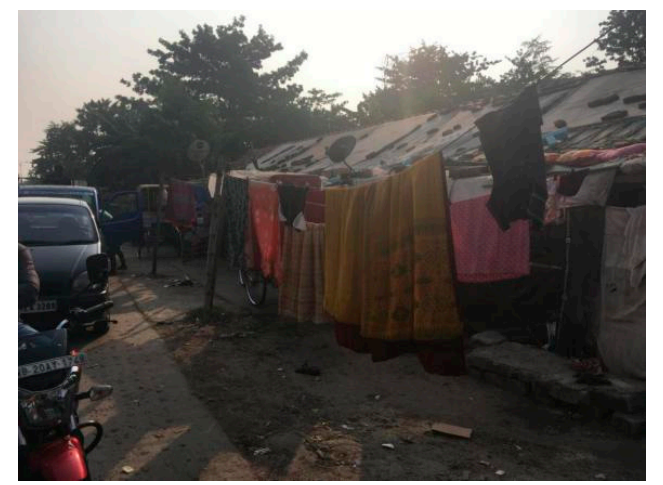

(d) Image 4: The resettlement colony adjacent to the main road

Figure 3. Cont. 


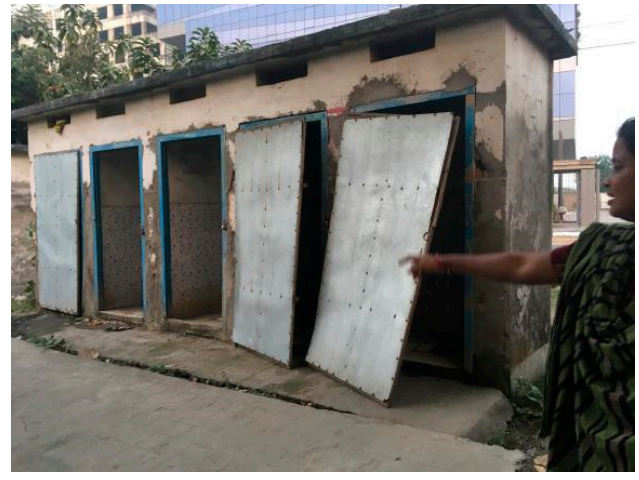

(e) Image 5: The dysfunctional toilets in the resettlement colony

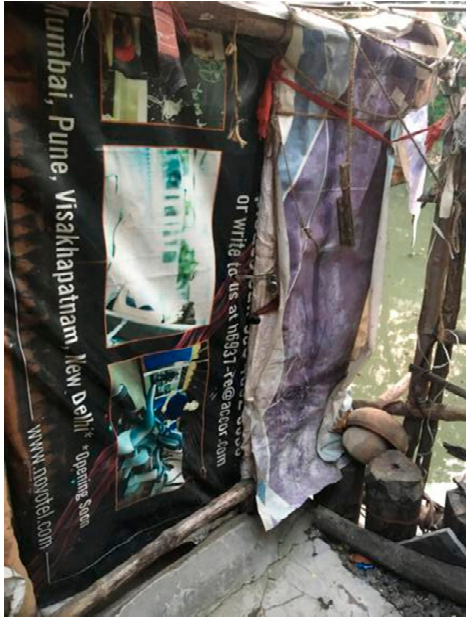

(f) Image 6: A makeshift toilet made by a resident

Figure 3. Life in the Nonadanga resettlement colony. Source: Author.

\subsection{Negotiating Fundamental Rights and Inclusiveness}

The lives of the migrants in Nonadanga have been ones of constant negotiation with urban governance authorities such as $\mathrm{KMC}$, the electricity department, the water department and the police for the basic needs of everyday life. This sub-section presents evidence of such deprivation. As mentioned before, Nonadanga is constituted of a number of fragmented squatters, of which one was razed and its inhabitants resettled. At a 5-min walk from the resettlement colony, one reaches another squatter settlement of thirtytwo households (Figure 4a,d). This squatter settlement was spared from the wrath of the eviction; however, its dwellers participated in the Nonadanga movement to protect themselves from future eviction. Following the movement, KMC provided the dwellers with citizenship rights and assured no further eviction. Moreover, they were promised toilets and electricity connections to the squatter settlement. However, the everyday living conditions in this squatter settlement are far worse than in the resettlement colony. "You see, they gave us the right to live here, but there was no electricity, water, toilets", said Mustafa (68), an elderly man of the settlement. "We had to pay INR 100,000 (GBP 1055) to local politicians to get electricity line to the squatter". Another dweller, Ram (48), adds, "for so long, we have been requesting to make a proper toilet for us. Before an election, they promise to construct it for us, but after election they disappear. Nothing has happened to date. We continue to defecate openly". The dwellers have constructed a makeshift bathing space with a plastic cover for women (Figure $4 b$ ). The men prefer to bathe in the open. The same high drain that marks the resettlement colony's boundary is on the opposite side of the squatter settlement. In front of this squatter settlement, the high drain (Figure 4c) comes to an end, resulting in a massive collection of toxic waste at this point. Along the drain, the inhabitants have constructed a toilet for the easy drainage of waste into it. Under government schemes for the disenfranchised, some of the inhabitants work as manual scavengers in this same drain that they use for defecating. 


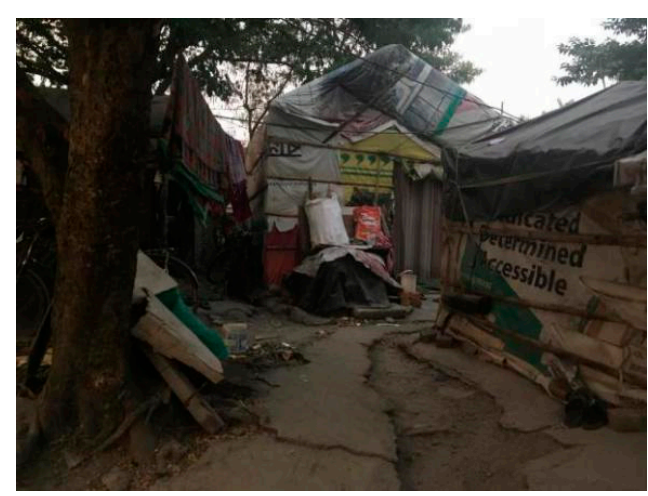

(a) Image 1: Squatter huts of Nonadanga.

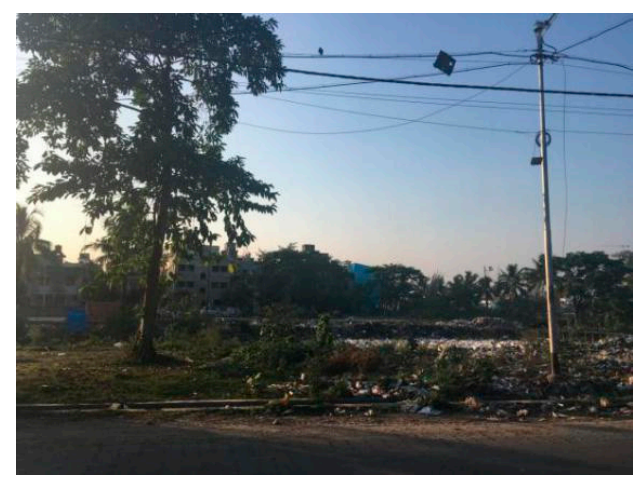

(c) Image 3: The high drain with garbage collected on the other side of the squatter.

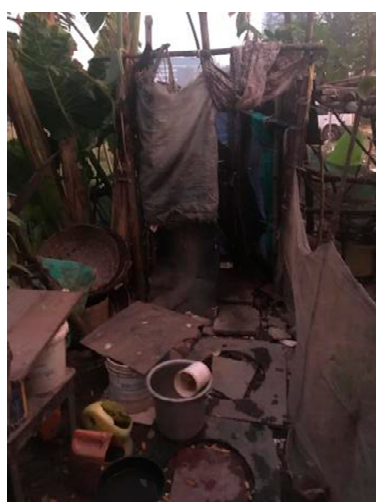

(b) Image 2: A makeshift bathing space for women.

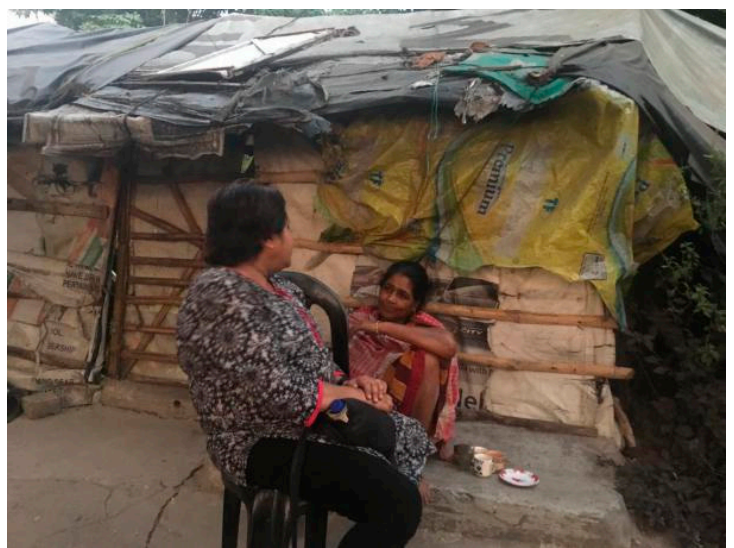

(d) Image 4: Inside the squatter settlement.

Figure 4. Showing everyday life of migrant in a squatter settlement in Nonadanga. Source: Author.

Urban migrants' interactions with state agencies do not end with occupancy rights but extend to their everyday lives, since their marginalized living conditions require them to negotiate every day with state authorities. The migrants occasionally encounter senior government officials, but most interactions are with the local political players or local police. This makes bribing, extortion, informal arrangements and illegality rampant in the squatter settlements. The evidence also points to a lack of endeavors from the urban governance side to make their lives holistically inclusive.

Migrants continue to live in the urban fringe in a state of partial inclusion where they enjoy occupancy rights but continue to live in uninhabitable conditions that deprive them of basic rights. To worsen the situation, they too, like the resettled inhabitants, suspect development-induced eviction in the future.

\subsection{Political and Social Consciousness, and Inclusiveness}

An essential dimension of inclusiveness is social inclusiveness $[45,46]$. Here, social inclusiveness has been viewed as developing individuals' (poor urban migrants) political and social consciousness through their urban experience in Kolkata. The dialectic of inclusion and exclusion at the same time promotes a sense of otherness in migrants, who have often recognized themselves in interviews as "people like us". The "like us" category is a socially constructed category that migrants perceive through embodied perceptions in everyday encounters. An analysis of the data demonstrates that it is a manifestation of a lack of dignity of life, experienced through a cycle of settlement, eviction, resettlement and everyday negotiations with power. Sati, a vocal and prominent face in the Nonadanga movement, sometime after the movement, died by suicide. People who knew her recall 
her views on the Nonadanga movement as "in the battlefield of life, resistance is the only way to live". It is undisputed in Nonadanga that marginalized urban migrants are used as political pawns. Pritam (37) says, "we have to go to every political meeting; otherwise, undesired consequences follow". Mustafa notes, "throughout my life in Kolkata, I have attended numerous political meetings and movements. We were asked to go by local party workers. The information reached us from the top through these political networks". Pritam adds, "only people like us go". It is mandatory for every household to have at least one representative present in political rallies. This is an unnegotiable political practice existing in the squatter settlements and slums of Kolkata. Ignoring the dwellers' personal political rights to choose which parties they wish to represent, they are mandated to attain meetings and rallies by the party in power. By using their agency to vote, Pritam adds, "I however, vote for the party I wish to vote. They cannotforce me to vote for them, they can only force me to attend their rallies". Additionally, migrants understand that government authorities change after every five years; however, they are there to stay, which pushes them to continue the struggle for inclusion and rights.

\subsection{Dialectic of Inclusiveness and Partial Rights}

The cycle of eviction and resettlement, the poor living environments in resettlement colonies, and continuous negotiation for basic needs such as electricity and toilets leaves migrants with an ongoing feeling of resistance and negotiation. As a consequence, migrants are included in the political fabric as potential voters but are excluded from a socially conducive quality of life that every citizen deserves.

The actual nature of the dialectics of inclusiveness as practiced by the urban governance system in Kolkata is presented in the section above with evidence from the field. This paper identifies the contradictory situation of inclusion as well as exclusion as partial rights, where the subaltern migrants of Nonadanga on Kolkata's urban fringe live in conditions of partial rights. Their rights are partial because the dialectic stance of governance agencies maintains the status quo in urban migrants' overall quality of life (Figure 5). In Nonadanga, the urban migrants were given occupancy rights, which entail citizenship rights, by formally enrolling them into the electoral process. Despite this, there is little or no improvement in their living conditions and environment. Social and political exclusion continues to operate as those in power use their subaltern identities for political gains. In the case of Nonadanga, this was achieved by creating the spectacle of resettling evicted migrants. The resettlement, however, did not ensure a basic quality of life. From a long-term sustainability and inclusiveness perspective, people living under partial rights conditions are excluded from a basic quality of life and, thereby, holistic inclusiveness. Citizenship rights do not ensure secured occupancy rights or an improved quality of life, preventing them from living the dialectic life of a citizen, as a disenfranchised migrant in Kolkata.

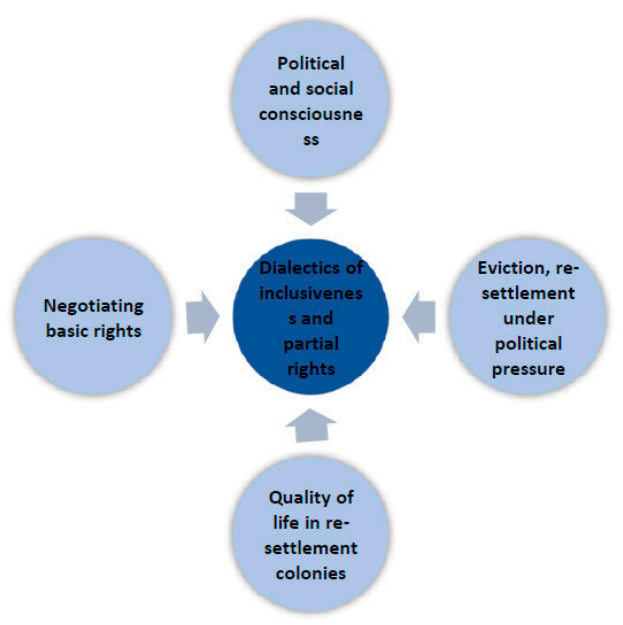

Figure 5. Showing the dialectic of inclusiveness emerging from structure-agency interaction. 
Besides their socially constructed definition, partial rights also have an embodied perception, experienced by the migrants of Nonadanga as a feeling of otherness. Partial rights are a condition constructed from migrants' voices and everyday lives. They are a condition that migrants perceive through senses such as seeing, smelling and feeling everyday urban exclusion. It is a condition in which subaltern migrants such as Hari, Soma, Ram, Mustafa and many others experience everyday uncertainties. The material environment of informal settlements, comprising housing quality, toilets, availability and access to resources such as electricity, evokes a familiar feeling of exclusion and marginalization. Partial rights emerge since such exclusions exist and proliferate because of the interaction between a partial state gaze and subaltern agency. Thus, the state both allows and denies migrants the right to a dignified life. The migrants' ability to negotiate with the state in such a matter is also crucial in determining the nature of partial rights. In Nonadanga, a prolonged movement, the incarceration of protesters, losses of livelihood and the need to close a settlement deal resulted in partial rights. Even after eight years of struggle, the KMC's assurance that the evicted land would be developed as a housing project for the urban poor has not happened.

Additionally supporting the argument of partial rights and the dialectics of inclusiveness are the recent state-government-initiated beautification projects across the city [40,46-48]. There have been a number of recent beautification projects in Kolkata zigzagging from north to south and east to west. The replica of London's Big Ben near the airport reinforces the state government's intent to make Kolkata a world-class city in which its poor population has no place. There is not a single project for the urban poor to ensure a holistic development of and improvement in their socio-economic conditions and long-term inclusiveness.

\section{Discussion: Kolkata and Sustainable Development Goals 2030}

Building on the discussion connecting evidence from the field, based on an analysis of expert interviews and consultations, this section describes three future scenarios in which Kolkata could achieve SDG 11 by 2030. The extension of the dialectics of inclusiveness to these sections is important for understanding the role of urban governance in the city's future.

\subsection{Scenario I: Continue to Live In Situ}

The first scenario is based on the assumption that migrants continue to live in situ. The primary advantage of this scenario is that migrants can continue working informally close to their present settlement. Any future eviction jeopardizes the advantage of living close to the workplace, but there is little or no chance to improve their living environment and/or quality of life. They continue to live in the dingy huts by the side of the high drain, being exposed to diseases in an unsustainable living environment. As pointed out by some inhabitants, the resettlement huts are of poor quality, and some are already tilting towards the drain. Accidents due to heavy rain and storms are likely, especially during monsoon. In this scenario, their quality of life does not improve, although economic viability may be sustained since they continue to live close to their workspaces. The environmental, social and political living conditions are not sustainable. Under Scenario I, Kolkata will not achieve the SDG of inclusive cities and communities by 2030 without government intervention.

\subsection{Scenario II: Eviction and Re-Location to Dhapa}

In Scenario II, the entire population of Nonadanga is resettled at Dhapa, an erstwhile dumping ground for Kolkata's waste. This has been the government's favorite spot to relocate its urban poor in. Located east of Kolkata, Dhapa is isolated from the urban center. During interviews, many migrants mentioned that they were given an option of resettlement to Dhapa, an option that they rejected since they would then be cut off from work and economic networks in the city. Since most urban migrants in Nonadanga work 
in nearby areas as informal workers, moving to Dhapa will make it impossible for them to commute daily to Nonadanga for work. Scenario II would be economically and socially unsustainable and further downgrade their quality of life. This conclusion is corroborated by an expert who noted "there is no resettlement and re-habitation project ongoing in Dhapa. So where will they be housed?". Migrants moving to the peripheral location of Dhapa would lose their sense of belonging, social networks and connection that they have built over the years in the city. Moreover, the remote location of Dhapa would alienate them from the possibilities of urban life.

\subsection{Scenario III: Eviction and Re-Location to Any Place Near the Present Settlement}

In the interview, migrants were asked about their courses of action in the event of another eviction. Some said they had written evidence from KMC supporting their occupancy rights; others said the state government and KMC could evict them at any time and that no written confirmation could save them in such an eventuality. Others said they would again protest against any eviction. All respondents stressed their wish to continue living in Nonadanga but with a better environment.

This scenario is based on the experience of the urban poor during previous KMC resettlement and rehabilitation programs implemented as part of the Kolkata Improvement Trust Programme (KITP) in 2000. Migrants from the canal side, along railway lines and from different parts of Kolkata, were relocated in Nonadanga and other areas in Kolkata [33]. The one-room units offered to evictees as a part of the resettlement program were generally inadequate for families of four, five or even more. The living conditions, deemed "living in cages", prompted many migrants to sell their units and move elsewhere. Given the history of migration to Kolkata, there is little possibility that state agencies will adopt sustainable $R \& R$ practices in Nonadanga. The need to $R \& R$ innumerable urban migrants, and the cost of doing so, provide incentives to authorities to adopt immediate and short-term measures. These short-term practices will probably prevent Kolkata from reaching SDG 11 by 2030.

All three scenarios result in the possibility of the urban poor living in a partial rights condition until 2030. The increasing number of climate migrants from Sundarban and the surrounding area coming to Kolkata will further complicate the situation. The ongoing failure to acknowledge climate change as a disaster excludes those affected from government assistance. They have no choice but to migrate to cities such as Kolkata.

\section{Conclusions}

This paper attempts to answer the overarching question, can Kolkata become an inclusive city as per SDG 2030? The paper focuses on the lives of the urban poor for answers. By extending the sustainability question to the inclusivity and quality of life of the poor urban migrants, the paper explores four sub-themes: development-induced eviction, resettlement due to political pressure, the quality of life in resettlement colonies, negotiating fundamental rights and everyday life, and the development of political and social consciousness. This demonstrates how structure-agency interaction produces a dialectic-of-inclusiveness framework in Nonadanga. The paper makes a theoretical contribution by extending the concept of the dialectics of inclusiveness to introduce partial rights, where partial rights are a condition of unsustainable and poor standards of quality of life, maintained under a partial state gaze.

The analysis of three future scenarios shows that there are limited opportunities for Kolkata to become an inclusive city by 2030. A complete overhaul of the political approach regarding urban migrants and urban poor as temporary permanents could bring real change. The benefits of creating inclusive societies by restoring the dignity of the urban poor could have immense long-term benefits. On the other hand, the lack of political will to create long-term societal benefits is likely to prevent Kolkata and major cities of India from achieving SDG 2030. 
Author Contributions: Conceptualization, A.C.; formal analysis, A.C.; investigation, A.C.; methodology, A.C.; resources, R.T. and H.B.; supervision, R.T. and H.B.; visualization, A.C.; writing-original draft, A.C.; writing-review and editing, A.C., R.T. and H.B. All authors have read and agreed to the published version of the manuscript.

Funding: This research received no external funding.

Informed Consent Statement: Informed consent was obtained from all subjects involved in the study.

Data Availability Statement: The data is held with the corresponding author.

Conflicts of Interest: The authors declare no conflict of interest.

\section{References}

1. Cruz, N.F.; Rode, P.; Mcquarrie, M. New urban governance: A review of current themes and future priorities. J. Urban Aff. 2019, 41, 1-19. [CrossRef]

2. De Sousa, L.; Moriconi, M. Why voters do not throw the rascals out?-A conceptual framework for analysing electoral punishment of corruption. Crime Law Soc. Chang. 2013, 60, 471-502. [CrossRef]

3. Tavares, R. Paradiplomacy: Cities and States as Global Players; Oxford University Press: New York, NY, USA, 2016.

4. Rhodes, R. Understanding Governance: Policy Networks; Governance, Reflexivity, and Accountability; Open University Press: London, UK, 1997.

5. Certeau, M.D. The Practicw of Everyday Life; University of California Press: Berkeley, CA, USA, 1988.

6. Chatterjee, P. The Politics of the Governed; Columbia University Press: New York, NY, USA, 2006.

7. Yiftachel, O. Critical Theory and 'Gray Space': Mobilization of the Colonized. City 2009, 13, 246-263. [CrossRef]

8. McFarlane, C.; Silver, J. Navigating the city: Dialectics of everyday urbanism. Trans. Inst. Br. Geogr. 2017, 42, 458-471. [CrossRef]

9. Roy, A. Ethnographic circulations: Space-time relations in the worlds of poverty management. Environ. Plan. A 2012, 44, 31-41. [CrossRef]

10. Dupont, V. Peri-urban Fynamics: Population, Habitat and Environamnt of LArge Indian Metropolises. CSH Occas. Pap. 2005, 14, 144.

11. Harvey, D. From Managerialism to Urban Entrepreneurialism: The Transformation in Urban Governance in Late Capitalism. Geogr. Ann. Ser. B Hum. Geogr. 1989, 7, 3-17. [CrossRef]

12. Stone, C. Regime politics: Governing Atlanta 1946-1988; University Press of Kansas: Lawrence, KS, USA, 1989.

13. Pierre, J. Can urban regimes travel in time and space? Urban regime theory, urban governance theory, and comparative urban politics. Urban Aff. Rev. 2014, 50, 864-889. [CrossRef]

14. Roy, S.; Samanta, G. Informal Labours in Kolkata City: Migration from Undivided Bihar and Uttar Pradesh. Space Cult. India 2020, 8, 143-159. [CrossRef]

15. Dasgupts, A.; Chakraborty, S.R. The Growth of Calcutta: A Profile of Social Dislocations in the Early Colonial Period. Soc. Sci. 1992, 20, 35-48.

16. Bose, P. Dilemmas of Diaspora: Partition, Refugees, and the Politics of "Home". Refuge Can. J. Refug. 2006, 23, 58-68. [CrossRef]

17. Samaddar, R. Migrant and the neo-liberal city. Econ. Political Wkly 2016, 54, $26-27$.

18. Bose, A. Studies in India's Urbanization, 1901-1971; Tata McGraw Hill: Bombay, India, 1973.

19. Dey, I.; Samaddar, R.; Sen, S.K. Beyond Kolkata Rajarhat and the Dystopia of Urban Imagination; Rotledge: New Delhi, India, 2016.

20. Roy, A. Why India Cannot Plan Its Cities: Informality, Insurgence and the Idiom of Urbanization. Plan. Theory 2009, 8, 76-87. [CrossRef]

21. Sassen, S. The global city: Introducing a concept. Brown J. World Aff. 2005, 11, 27-40.

22. Roy, A. City Requiem, Calcutta: Gender and the Politics of Poverty; University of Minnesota Press: Minneapolis, MN, USA, 2013.

23. Lodge, M.; Wegrich, K. 2014: Administrative Capacities. In The Governance Report 2014; Oxford University Press: Oxford, UK, 2014; pp. 27-48.

24. Wegrich, K.; Štimac, V. Coordination Capacity. In The Problem-Solving Capacity of the Modern State: Governance Challenges and Administrative Capacities; Lodge, M., Wegrich, K., Eds.; Oxford University Press: Oxford, UK, 2014; pp. 41-62.

25. Lee, C.; McQuarrie, M.; Walker, E. Democratizing Inequalities: Dilemmas of the New Public Participation; New York University Press: New York, NY, USA, 2015.

26. Transforming Our World: The 2030 Agenda for Sustainable Development; A/RES/70/1; UNDP—United Nations Development Programme: New York, NY, USA, 2016.

27. Bhan, G. Notes on a Southern urban practice. Environ. Urban. 2019, 31, 639-654. [CrossRef]

28. Benjamin, S. Occupancy urbanism: Radicalizing politics and economy beyond policy and programs. Interna-tional. J. Urban Reg. Res. 2008, 32, 719-729. [CrossRef]

29. Parnell, S. Oldfield, S. The Routledge Handbook on Cities of the Global South; Routledge: London, UK, 2017.

30. Duff, C. The affective right to the city. Trans. Inst. Br. Geogr. 2017, 42, 516-529. [CrossRef]

31. Purcell, M. Possible worlds: Henri Lefebvre and the right to the city. J. Urban Aff. 2014, 36, 141-154. [CrossRef]

32. Lefebvre, H. Writing on Cities; Blackwell Publisher: Oxford, UK, 1996. 
33. Giddens, A. The Constitution of Society: Outline of the Theory of Structuration; Polity Press: Cambridgeshire, UK, 1984.

34. Burkitt, I. Relational agency: Relational sociology, agency and interaction. Eur. J. Soc. Theory 2015, 19, 322-339. [CrossRef]

35. Morse, J.M. Designing funded qualitative research. In Handbook of Qualitative Research; Denzin, N.K., Lincoln, Y.S., Eds.; Sage Publications Ltd.: Thousand Oaks, CA, USA, 1994; pp. 220-235.

36. Wiles, J.L.; Rosenberg, M.W.; Kearns, R.A. Narrative analysis as a strategy for understanding interview talk in geographic research. R. Geogr. Soc. 2004, 37, 89-99. [CrossRef]

37. Attride-Stirling, J. Thematic networks: An analytic tool for qualitative research. Qual. Res. 2001, 1, 385-405. [CrossRef]

38. Bose, P. Refugee, Memory and the State: A Review of Research in Refugees Studies; Mahanirban Calcutta Research Group: Salt Lake Kolkata, India, 2010; Available online: http:/ / www.mcrg.ac.in/rwfiles/RW36/1.Pradip.pdf (accessed on 22 September 2020).

39. Banerjee-Guha, S. Nonadanga Eviction. Econ. Political Wkly. 2012, 17, 13-15.

40. Sengupta, U. The hindered self-help: Housing policies, politics and poverty in Kolkata, India. Habitat Int. 2010, 34, 323-331. [CrossRef]

41. Mancha, N. Canal Bank Dwellers: Displacement in the Name of Development Kolkata; Sanhati Publication: Kolkata, India, 2010; Available online: http:/ / sanhati.com/excerpted/2321/ (accessed on 25 September 2020).

42. Shaw, A.; Saharan, T. Urban development-induced displacement and quality of life in Kolkata. Environ. Urban. 2019, 31, 597-614. [CrossRef]

43. KMDA May Lease Out Nonadanga land. Times of India. 17 April 2012. Available online: https://timesofindia.indiatimes.com/ city/kolkata/KMDA-may-lease-out-Nonadanga-land/articleshow/12697960.cms (accessed on 25 September 2020).

44. Soja, E. Thirdspace: Journeys to Los Angeles and Other Real-and-Imagined Places; Wiley-Blackwell Publisher: Hoboken, NJ, USA, 1996.

45. Hussein, F.; Stephens, J.; Tiwari, R. Memory for Social Sustainability: Recalling Cultural Memories in Zanqit Alsitat Historical Street Market, Alexandria, Egypt.MDPI. Sustainability 2020, 12, 8141. [CrossRef]

46. McGranahan, G.; Schensul, D.; Singh, G. Inclusive urbanization: Can the 2030 agenda be delivered without it? Environ. Urban. 2016, 28, 13-34. [CrossRef]

47. Haque, I. Discriminated urban spaces: A study of spatial segregation in urban West Bengal. Econ. Political Wkly. 2016, 51, 41-50.

48. GDP: The Top 10 Cities in India. Rediff. Available online: https://business.rediff.com/slide-show/2010/apr/23/slide-show-1the-top-10-cities-in-india-by-gdp.htm (accessed on 27 September 2020). 